\title{
Ho Chi Minh's Thought on Moral Education of the Youth in His Testament
}

\author{
Pham Ngoc Loi, Ph.D* \\ The Dean of Faculty of Public relations and Social work, Ho Chi Minh City Cadre Academy, Ho Chi Minh City,
} Vietnam

*Corresponding Author: Pham Ngoc Loi, Ph.D, The Dean of Faculty of Public relations and Social work, Ho Chi Minh City Cadre Academy, Ho Chi Minh City, Vietnam

\begin{abstract}
President Ho Chi Minh's testament is a political document written by President Ho Chi Minh. It shows the intention, affection, spirit, faith and responsibility of President Ho Chi Minh to the Fatherland, the people and the revolutionary cause. It provides instructions for Communist Party of Vietnam to lead our people to win national independence. In the testament, President Ho Chi Minh highlighted the importance of training and education of the country's next generation. This paper aims to analyze Ho Chi Minh's thought on moral education of the youth in his testament. It also gives some suggestions to improve moral education for the youth in Vietnam at present.
\end{abstract}

Key words: moral education, testament, the youth, Ho Chi Minh's ideology

\section{INTRODUCTION}

President Ho Chi Minh - the genius and beloved leader of the Vietnamese nation, is also the brilliant communist of the international communist movement. He left to our Party and people an invaluable ideological legacy including his testament. On the occasion of his 75th birthday, at 9 am on 10 May 1965, Uncle Ho wrote his Testament comprising three pages typewritten by himself and dated May 15, 1965 at the end. This was a complete Testament, bearing his signature, and on the side, that of Comrade Le Duan, First Secretary of the Party Central Committee at the time. In 1966 and 1967, he wrote no separate pages. In 1968, he added a few more paragraphs including 6 handwriting pages. In the 1968 edited version, the late President rewrote the opening paragraph and another paragraph about "private matters" he wrote in the 1965 version and added a few more paragraphs. On May 10, 1969, President Ho Chi Minh rewrote the entire opening of the testament, including a handwritten page. Later, during the days from 11 to 19 May 1969, Uncle Ho continued to revise the Testament of 1965 version, 1968 version and 1969 version. At 10 o'clock on May 19, 1969, on the anniversary of Uncle Ho's 79th birthday, he read all the versions of the testament that he had written earlier, put them in an envelope and put them away. The testament of President Ho Chi Minh was first announced at his Funeral Ceremony in September 1969, including 4 pages of print size of $14.5 \mathrm{~cm}$ x $22 \mathrm{~cm}$. On August 19, 1989, the Politburo issued Notice No. 151-TB / TW on a number of issues related to the will and the date of President Ho Chi Minh's pass away affirming that the will officially announced in 1969 was faithful to his originals. On the occasion of the 100th birthday anniversary of President Ho Chi Minh, the Politburo of the Party Central Committee (Session VI) decided to publish all of the versions of his testament. Ho Chi Minh's Testament with 1000 words conveyed the contents and messages expressing the great thought of the leader who sacrificed his whole life to the country and the people. His testament includes: the reasons to write the testament, affirming the determination and belief in Vietnamese people's victory in a war against America, showing the solidarity tradition and measures to strengthen the unity within the Party, cultivating young generation, taking care of the people's lives, showing the work must be done after winning in the war against America, the communist movement of the world. He also wrote about his own affairs and showed his endless love for the nation and the people in the testament. After talking about the Party, Ho Chi Minh discussed the importance of education of the country's next generations. He affirmed that "Fostering revolutionary morality for the next generation is a very important and very necessary task" [1] 


\section{Humanism in President ho Chi Minh's Testament}

Humanism is the red thread throughout Ho Chi Minh's thought. It is the source and basis determining the goals of his revolutionary activities. Ho Chi Minh's testament is an invaluable historical document. With his brief and concise instructions, he affirmed the inevitable victory of the cause of anti-American national salvation, summed up the Party's revolutionary leadership experience, outlined the directions as well as the "tasks" need to be done first "for the cause of national construction after the resistance victory. The value and meaning of the Will is not only due to the broad scope and his vision of the revolutionary issues but also his infinite love and kindness.

His words in the testament demonstrated the heart of a great person who "served the Fatherland, the revolution and the people with all my heart and strength" [2]. He showed his regret for "not being able to serve for his nation and people more and longer". In the last part of the testament, he wrote: "In the end, I leave all of my love to all the people, the whole Party, to all the army, young people and children" [3]. His love is not only shown in words but also in his deep and specific concern for the Party and people. For the Party, with the leading and ruling role; therefore, he required the Party to uphold the tradition of solidarity, revolutionary morality and comradeship. For the youth, he concerned about their role and maturity; therefore, it is necessary to train and educate them to become the successors of the revolutionary cause with fine moral virtues and skills. For the working people, he highly appreciated their contributions and understood their difficulties, so he required "a good plan" to constantly improve their lives. For the war invalid, he said that it is necessary to create conditions for them to be gradually "self-reliant". For the martyrs, he stated that it is necessary to pay tribute and educate the patriotism of the next generations through that gratitude. Ho Chi Minh did not forget any person or class; even with the victims of the old regime. "We need to transform them and help them to become good people", Ho Chi Minh said. According to President Ho Chi Minh, the important contents in cultivating young generations are improving revolutionary morality, teaching socialist ideology and eliminating individualism. It is no coincidence that he mentioned the moral qualities of the revolutionists as the first content of the book "the Revolutionary path". His ideas on revolutionary morality contain profound human views and for establishing personality, ideals and lifestyle standards for the younger generation. Revolutionary morality is an indispensable quality and the root of socialist people. He underlined the necessity of revolutionary morality: "It is similar to a river which must have a source. Without a source, the river will run out. A tree must have its root, if not, it will wither. Revolutionaries must have ethics, without which they will not be able to lead the people despite their talent" [4]. President Ho Chi Minh's concept of affection and love for people is not only the origin of character but also the value and meaning of human life since affection and love play a great role in forming and strengthening the good virtues of human personality. He wrote: "when your heart only serves for the Party, the Fatherland and the people, you will be impartial. If you have been impartial, your shortcomings will be less and good qualities will be more. In short these good virtues are humanity, justice, wisdom, courage and integrity" [5]. Thus, the formation of the virtues of human personality is not just through by memorizing requirements, social norms, or theoretical principles. Those requirements, standards, principles are also values; and acquiring these values includes the choice based on human emotions.

President Ho Chi Minh always highly valued the role of the younger generations who will succeed in the revolutionary career. With an objective scientific view, President Ho Chi Minh highly appreciated the role, position and ability of young people in the revolutionary cause of the Party and the nation. He stated, "The youth are the country's future masters. The country will prosper or become decadent, strong or weak, depending very much on the youth" [6]. In the Will, he wrote "Our Youth union members and young people are generally good. They are always ready to come forward, fearless of difficulties and eager for progress. The Party needs to take care of the revolutionary moral education for them and teach them to build socialism both "ethically" and "professionally". It is very necessary to educate and train revolutionary ethics for the future generation" [7].

\section{Moral Education of Young People According to ho Chi Minh's Ideology at PRESENT}

Unlike the previous young generation, today young people in our country have great happiness of living in independence and freedom. They have clear goals of studying, working and fighting. These goals are the lofty ideal of our times, socialism and communism. Moral education of young people according to Ho Chi Minh's thought now plays an important role in the development of our country. 


\subsection{Ho Chi Minh's Thought on Moral Education of Young People}

Educating the youth about revolutionary idealism. Idealism is extremely important in human life. Ideally, people should be motivated to act to satisfy their needs and interests. To be a human, everyone needs ideals to strive for. Especially at the young age - the most beautiful age of life, every young man in different conditions and positions has the highest and most beautiful dreams of his life. Young people are those who are perfecting their personalities. Young people aspire to implement the ideals towards social values, but they do not have enough experience in assessing and choosing values. Therefore, young people need the effects of social education to guide them to realize the ideal that our Party and people have chosen.

President Ho Chi Minh pointed out the noble and right ideals for communists and young people that is national independence and socialism. "Communists must never forget our noble ideal of striving for our country to be completely independent and for socialism to be completely victorious in our country" [8]. Every young person must shape for himself ideals of life in line with the common ideology of the nation, making his contribution into struggle to win national independence and build socialism.

Educating the youth about patriotism: To teach young people about morality, Ho Chi Minh highlighted two characters: loyalty and filial piety. One of the five things he taught children the first is: "Love your country, love your people". For young people, the most important thing is that they should love the nation and people, having national spirit and a proper international spirit". Young people must be willing to fight for their country, loyal to the Party and upright. The word "loyalty" in feudal dynasties means "loyal to the King". This quality was expanded by Ho Chi Minh with new contents that was "absolutely loyal to the country, to the people, to the revolution". To be loyal to the country means that young people must be faithful to the cause of building and defending the country, with the path of national development and development. They must put the interests of the nation above personal interest to implement revolutionary objectives, all guidelines and policies of the Party. In that way, Ho Chi Minh transformed the moral standard into revolutionary morality.

"Loyalty" associated with "filial piety", Ho Chi Minh has expanded the moral standards from the scope of the family to the whole society. There is a unified relationship between the quality "loyalty" and "filial piety". "The Party takes care of the people, the country and everyone. So being loyal to the Party, you have to be filial to the people". That is the unity between the national stance and the class position.

Instructing at the 2nd student congress in 1958, Ho Chi Minh said that the youth must be taught to love the Fatherland, the people, socialism, work and science and technology in which love for the homeland and the people is the first requirement. Love the country, young people need to make it rich and strong. In order for the country to be rich and strong, it is necessary to work harder, increase production and practice thrift. According to him, the best way to foster patriotism for young people is to teach them national and revolutionary traditions. Through traditional education, good values such as national pride, awareness and willingness to devote themselves to national independence and sovereignty are strengthened so that young people can see the great value and significance of a peaceful, free and independent life. These values become sentiments motivating young people to overcome all difficulties to protect the independence and national sovereignty, and build a peaceful, prosperous and happy life.

Educating the youth about revolutionary morality: Ho Chi Minh paid special attention to revolutionary moral education for the young generation. This is the first task, because he pointed out that "young people must always practice revolutionary morality". It is necessary to make young people to aware that revolutionary morality means "recognizing rights and wrongs, standing their ground, being loyal to the country and devoted to the people". The core content of revolutionary ethics is diligence, thrift, integrity, righteousness and impartiality.

Diligence, thrift, integrity, and righteousness are four essential qualities for everyone in general and young people in particular. The youth need to practice these four qualities to perfect their personality. Impartiality means not thinking of yourself first. Practicing impartiality also means resolving to wipe out individualism and to enhance revolutionary morality. 
The revolutionary moral education of young people is also an education on the love for people. According to Ho Chi Minh, revolutionists are rich in love. Because of the love for people, they have to carry out revolutions and accept all the hardships and sacrifices to bring prosperous and happy lives for people. The people that Ho Chi Minh refers to are the specific people around us. They are family members, brothers, relatives, companions, comrades, compatriots and all humanity. As for him, first and foremost, we need to respect their human dignity. In the Will, he also told the Party to have comrades love each other and strive for a common ideal.

In order to teach young people about revolutionary morality, Ho Chi Minh also taught them not to be afraid of difficulties and sufferings. Where there is a need, young people will appear; where there is difficult task, young people will do. The task of young people is not only to study, but also the willingness to make sacrifices.

Educating young people to eliminate individualism. In ethical education for the younger generation, Ho Chi Minh paid attention to teach them to give up individualism. "It is the mother who gives birth to all bad natures like: laziness, decadence, arrogance, bugle, shyness, waste, embezzlement, etc., it is the evil enemy of the revolutionary morality and socialism" [9]. Further emphasizing the importance of the struggle to abandon individualism, he said that in order to do that effectively, each person must join in the collective himself, to strive for the benefit of collective. Collective interests must be placed above individual interests. Therefore, it is necessary to train the youth revolutionary morality to help them imbued with socialist ideology and believe in the leadership of the Party and the people's wisdom.

Young people are enthusiastic in all common work; therefore, President Ho Chi Minh put his faith in the young generation. In order to educate young people, Ho Chi Minh inherited the traditional concepts and at the same time skillfully introduced new content, suitable to the revolutionary situation of our country into the content of these concepts. Thus, the content of Ho Chi Minh's thought on ethical education of the youth includes: educating revolutionary idealism, patriotism, revolutionary moral education and teaching them to eliminate individualism.

\subsection{The importance of educating the youth about revolutionary morality}

Firstly, patriotism needs to be highly promoted to help our country overcome poverty and backwardness. It can be affirmed that teaching patriotism for young people in Ho Chi Minh's thought is an important work which will enhance strength and creativity to millions of young people to make contribution in all fields of the society for the sake of our country and our people. Ho Chi Minh's ideas on teaching young people patriotism today are still topical and valuable. Although our country achieved independence and freedom, we still face many difficulties and challenges such as poverty and backwardness. The cause of national construction, bringing our country's economy up to the level of the region and the world requires young generation to strive and make more dedication efforts. Young people need to be voluntarily trained and they need to improve themselves to become people with the will, energy and ambition to overcome low temptations, bad habits and negative impacts of the market economy and globalization.

Secondly, to improve the quality and capacity of young people, attention must be paid to comprehensive education. According to Ho Chi Minh, young people need to study political theory, science, technology and culture. The most important thing is that they have to be imbued with socialist ideology and wipe out individualism. That is particularly important, especially in the context of the rapid development of modern science and technology. Vietnamese youth must master the most advanced technologies to eliminate poverty and close the gap with developed countries. The fact today shows that many young people have been worthy of his teachings. Glorious victories of Vietnamese youth in international competitions, in production and business have shown the creative capacity of Vietnamese youth. However, young generation need to do more than that They need to continue to study and improve themselves. We not only teach young people knowledge but also moral qualities. At present, many young people are engrossed in pursuing material values and enjoyment, so they forget their great responsibility to the country. Bad habits and social evils are damaging a number of teenagers who are not self-studying and practicing. Many of them are falling into an unreasonable life, without right orientation. This is also the cause of the rise in crimes among young people. In this situation, more attention should be paid to ethical education of young people according to Ho Chi Minh's thought. 
Thirdly, the moral qualities mentioned by Ho Chi Minh are essential for today's youth. It is the courage, the patriotism, diligence, thrift, integrity and righteousness. According to President Ho Chi Minh, young people need to be brave and creative. They need to have enthusiasm and the spirit to go ahead to overcome all difficulties and hardships to go forward forever. In any case, young people must be worthy of the glorious tradition of the nation. In the context of integration and opening up today, the country is facing great opportunities and challenges, the role and responsibility of young people and youth are even more important. The future of the country depends on the younger generation.

Fourthly, our country is still facing many difficulties when the mechanisms and policies are not really comprehensive. In schools and agencies, there still exist shortcomings and common diseases such as achievement disease, the spread of injustice, fraud in examinations have not been completely overcome. In these conditions, we must follow Ho Chi Minh's instructions, that is whatever the difficulty, we must be determined to teach well and learn very well.

In order to improve the quality and effectiveness of moral education for young people, we need to have specific measures.

\section{SOLUTIONS TO IMPROVE MORAL EDUCATION OF THE YOUTH}

First, families, schools and the society should coordinate in moral education of young people. This matter is crucial to the success or failure of moral education for young people. There must be an agreement on views, content and methods in moral education for young people between families and schools. The family must always get access to the information from the school so as not to obstruct children in participating in movements of schools. If the families, schools, and the society do not have a close coordination in teaching morality, lifestyle, political ideology for the youth, a lot of young people may commit crimes.

Second, organizing cultural activities, sports, and social activities for the youth to participate in. Young people today live in a diverse cultural environment. They may get access to many domestic and international sources of information and different cultures which has a great impact on the spiritual life and lifestyle of young people. The youth are very sensitive to social and political issues. Therefore, families and schools should coordinate with the authorities, socio-political organizations, economic organizations and people's armed forces units in localities to organize cultural activities, sports, and social activities for the youth to participate in. These are very useful activities, helping young people to improve their health and the sense of responsibility to the community. Close association between the family, school and society in ethical education for young people is a very basic solution of socialist ethical education, creating all favorable conditions for educating values, national traditions, and at the same time step up the fight against conservative ideas, backward customs and practices that prevent the development of society, contributing to the expansion of international exchange and selective acquisition of human culture.

Third, encouraging the youth to find a suitable job. Entering the youth, each person must set for themselves a career choice to prepare for an independent life. This is a very important issue in the life of each person. Families, schools and the entire society, including youth unions, youth associations will support them. But the important thing is that every person must be self-responsible for his life, and happiness associated with his responsibility of a family member a citizen of the state. Since each family is a cell of society, developing oneself, developing a healthy and good life in each family is contributing to building and developing social community. Young people who come into life to become an honest and healthy person must go through a practical working environment. A job can yield creativity and spur innovation for the youth. If young people are unemployed, they easily fall into criminality and violence. Therefore, creating jobs for young people is the responsibility of the society to people. The State and social organizations, Youth Union organizations need to take effective measures and policy orientations for employment and careers for young people. Vocational training and apprenticeship among the youth in rural areas are even more urgent than ever. The basic foundation of choosing a career is working, especially the affection and working attitude of each person. Therefore, for young people, vocational education is essentially teaching working attitude, improving knowledge, training labor skills for them to work independently.

Fourth, creating a healthy social environment for moral education of young people. In order to improve the effectiveness of moral education of young people, we need to build a healthy social 
environment and create favorable conditions for the formation of new moral standards among young people. The living environment has a great influence on the personality, morality, and lifestyle of young people. To build a cultural and social environment associated with the construction of cultural families, cultural villages and cultural societies, at the same time, enhancing the education of awareness of preventing social evils are an extremely pressing demand. Building a healthy cultural environment is also creating "self-immunity" for each person and each family against the extremely dangerous attacks of non-cultural, anti-cultural and anti-human forces, crimes, evils, moral decay, irresponsibility, emotionless and inhumane attitudes in terms of market economy. Therefore, it is imperative to take care of the material and spiritual life of young people, promoting spiritual and cultural activities in various and diversified forms such as arts, sports, movies, radio and television and improving national pride in each young person, thereby helping them voluntarily cultivate and improve themselves according to the revolutionary ideal.

\section{CONCLUSION}

Young people must be worthy of the teachings of Uncle Ho: "The youth are the country's future masters. Indeed, the country is prosperous or weak, mostly by young people. If the youth want to be worthy of this title, they must educate and train their spirit and work hard to prepare for the future" [10]. Our Party believes that Ho Chi Minh Communist Youth Union and young people today will successfully fulfill the glorious mission of the Party and people for the new revolution period. Over the last 50 years since President Ho Chi Minh wrote his Testament, his instructions, his thoughts on education and training of the youth are still of great significance.

\section{REFERENCES}

[1] Ho Chi Minh (2011). Complete volume, Vol.15, Hanoi: National Political Publishing House, p.612.

[2] Ho Chi Minh (2011). Complete volume, Vol.15, Hanoi: National Political Publishing House, p.623.

[3] Ho Chi Minh (2011). Complete volume, Vol.15, Hanoi: National Political Publishing House, p.624

[4] Ho Chi Minh (2011). Complete volume, Vol.5, Hanoi: National Political Publishing House, p.292

[5] Ho Chi Minh (2011). Complete volume, Vol.5, Hanoi: National Political Publishing House, p.291

[6] Ho Chi Minh (2011). Complete volume, Vol.5, Hanoi: National Political Publishing House, p.216

[7] Ho Chi Minh (2011). Complete volume, Vol.15, Hanoi: National Political Publishing House, p.622

[8] Ho Chi Minh (1995). Complete volume, Vol.12, Hanoi: National Political Publishing House, p.93

[9] Ho Chi Minh (1995). Complete volume, Vol.13, Hanoi: National Political Publishing House, p.90

[10] Ho Chi Minh (2002). Complete volume, Vol.5, Hanoi: National Political Publishing House, p.185

\section{AUTHOR'S BIOGRAPHY}

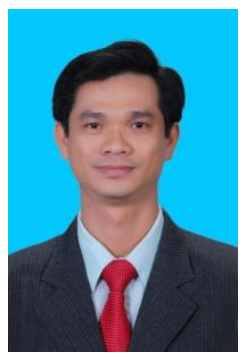

Pham Ngoc Loi, was previously a Deputy Secretary of Ho Chi Minh Communist Youth Union of District 12, Ho Chi Minh city. He was a chairman of the Youth Federation of District 12, Ho Chi Minh city. He also served as Vice-chairman of the People's Committee of Tan Thoi Nhat Ward, District 12, HCMC. He was a Deputy Director of the Political training center of District 12, Ho Chi Minh city. At present, he is the Dean of the Faculty of Public relations and Social work at Ho Chi Minh City Cadre Academy. He participated in many scientific research programs and projects at the academy, at ministerial-level and state-level. He is also a lecturer at the academy and teaching at some universities in Vietnam.

Citation: Pham Ngoc Loi, Ph.D. "Ho Chi Minh's Thought on Moral Education of the Youth in His Testament" International Journal of Humanities Social Sciences and Education (IJHSSE), vol 7, no. 5, 2020, pp. 14-19. doi: http://dx.doi.org/10.20431/2349-0381.0705002.

Copyright: (C) 2020 Authors. This is an open-access article distributed under the terms of the Creative Commons Attribution License, which permits unrestricted use, distribution, and reproduction in any medium, provided the original author and source are credited. 